\title{
Analysis of Holocene sedimentary features on the Adriatic shelf from 3D very high resolution seismic data (Triad survey)
}

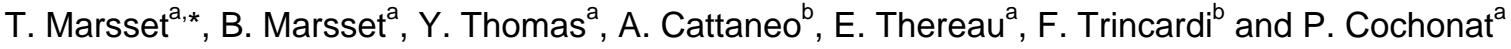 \\ ${ }^{a}$ IFREMER (Institut Français de Recherche pour l'Exploitation de la Mer), BP 70, 29280 Plouzané \\ Cédex, France \\ ${ }^{\mathrm{b}}$ ISMAR (CNR), v. Gobetti 101, 40129 Bologna, Italy \\ *: Corresponding author : Tel.: +33 2982242 06; fax: +33 2982245 70; email: tania.marsset@ifremer.fr
}

\begin{abstract}
:
Very High Resolution (VHR) 3D seismic data were collected on the Adriatic shelf offshore the city of Ortona in order to define the small-scale geometric complexity of late Holocene deposits. Three groups of units are distinguished from the bottom up: (1) units U1 to U3 forming the Transgressive System Tract (TST); (2) units U4 and U5 representing the condensed interval deposited on the Maximum flooding surface (MFS) and the basal unit of the High stand System Tract (HST); and (3) U6 to U10 forming the progradational units of the HST. The muddy HST deposits show seafloor and subsurface sedimentary features over up to $40 \%$ of its extent on the Adriatic shelf. In the area offshore Ortona, the HST shows shore-parallel undulations in water depth of ca. 30-70 m and mud reliefs in water depth of ca. 70-110 m. The mud reliefs are subcircular in plan view and occur in swarms, perpendicular to the regional contour, that are connected to each other by shore-parallel junctions. The genesis of these features is interpreted as a combination of two different mechanisms: (1) sediment deformation in relation with the condensed section; and (2) depositional process related to shore-parallel currents interacting with topographic irregularities. The evolution of the HST sedimentary pattern is closely related to a "key unit" (U5) that influences both the seaward transition from linear to complex features and the stacking pattern.
\end{abstract}

Keywords: Late Holocene; Adriatic shelf; 3D VHR seismic; sediment deformation; Bottom-hugging currents 


\section{Introduction}

On the Adriatic shelf (Fig. 1), the late-Holocene mud prism is affected by complex irregularities in the form of linear-crested seafloor undulations and near-circular mud reliefs over large extent of the seafloor (Trincardi et al., 2000; Correggiari et al., 2001) and by the presence of gas at different stratigraphic levels (Howland and Curzi, 1989; Conti et al., 2002 ; ). The interpretation of the origin of such complex features proved difficult using conventional 2D seismic data alone as observed for other settings worldwide (Gardner et al., 1999; Faugères et al., 2002; Lee et al., 2002). For this purpose, a small area was selected for a Very High Resolution (VHR) 3D seismic survey (Marsset et al., 2003a). The survey was conducted in an area covering a surface of $800 \times 3600 \mathrm{~m}$ at a water depth of 50-70 m (Fig. 1) where swath bathymetry and detailed stratigraphic data from piston cores are available (Cattaneo et al., 2003a).

The purpose of this paper is to provide a detailed description both of the geometry and the thickness distribution of the late-Holocene mud wedge to tentatively explain the origin of undulations and reliefs that have previously been ascribed either to bottom-current deposition or to sediment deformation.

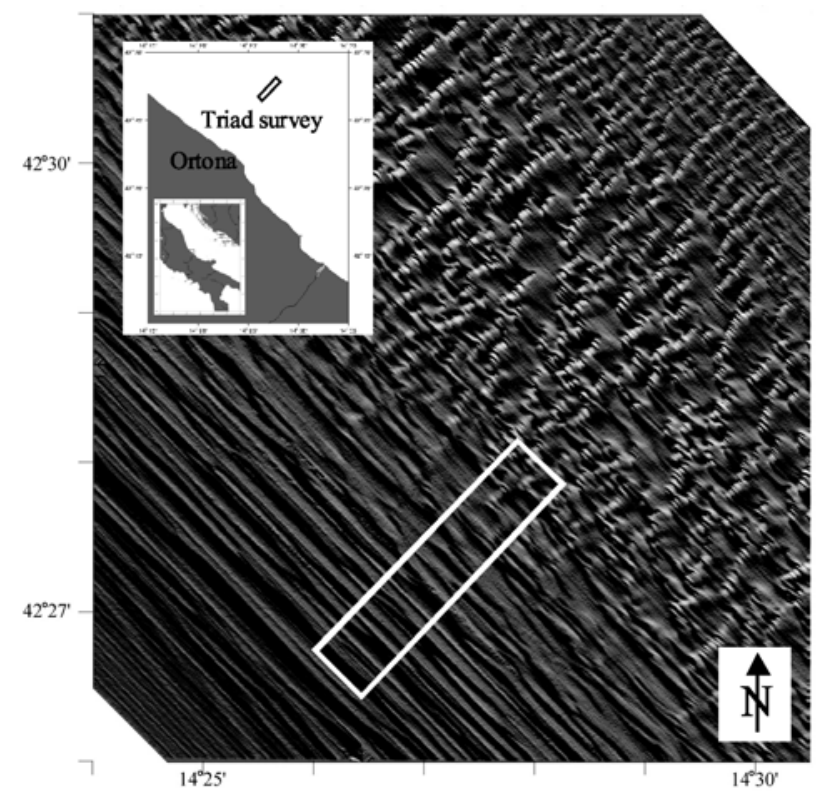

Figure 1. Location of the TRIAD survey in the central Adriatic Sea (the rectangle represents the area (800 $\mathrm{m} \mathrm{x}$ $3600 \mathrm{~m}$ ) covered by the 3D seismic survey); the map represents a shadowgram of the sea bottom (Cattaneo et al., 2003b) for water depth ranging from 30 to $\sim 100 \mathrm{~m}$.

\section{Background}

The shallow stratigraphic architecture of the west Adriatic margin is composed of different sedimentological units related to late Quaternary sea level changes (Fig. 2a; Cattaneo and Trincardi, 1999; Trincardi and Correggiari, 2000):

- The Prograding Pleistocene wedges are truncated at their top by a regional erosional surface (ES1) that records a regressive phase encompassing most of the last glacial cycle, from marine oxygen isotope stage $5 e$ to the base of the last glacial maximum (Trincardi and Correggiari, 2000; Ridente and Trincardi, 2002).

- The Transgressive System Tract (TST), above ES1, marks distinctive phases of the last sea level rise (Cattaneo and Trincardi, 1999) and reflects short-term variations of sediment supply and dispersal, likely accompanied by changes in the oceanographic regime of the basin (Asioli et al., 1999). The TST is made of a lower muddy unit intensely gas-charged and 
deposited in a shallow-water environment, a middle unit with shingled clinoform reflectors and centimetre-scale sand beds reflecting phases of increased sediment flux, and an upper muddy unit showing faint plane-parallel continuous reflectors.

- The Highstand System Tract (HST) consists of a shore-parallel prograding mud prism younger than 5.5 cal kyr BP that formed above a regional downlap surface (Maximum Flooding Surface, MFS; Correggiari et al., 2001). Multiproxy stratigraphic data indicate that the basal portion of the HST encompasses a thin condensed unit draping the MFS (Correggiari et al., 2001; Oldfield et al., 2003); this basal unit shows evidence of extensive deformation and possible fluid escape (Correggiari et al., 2001).
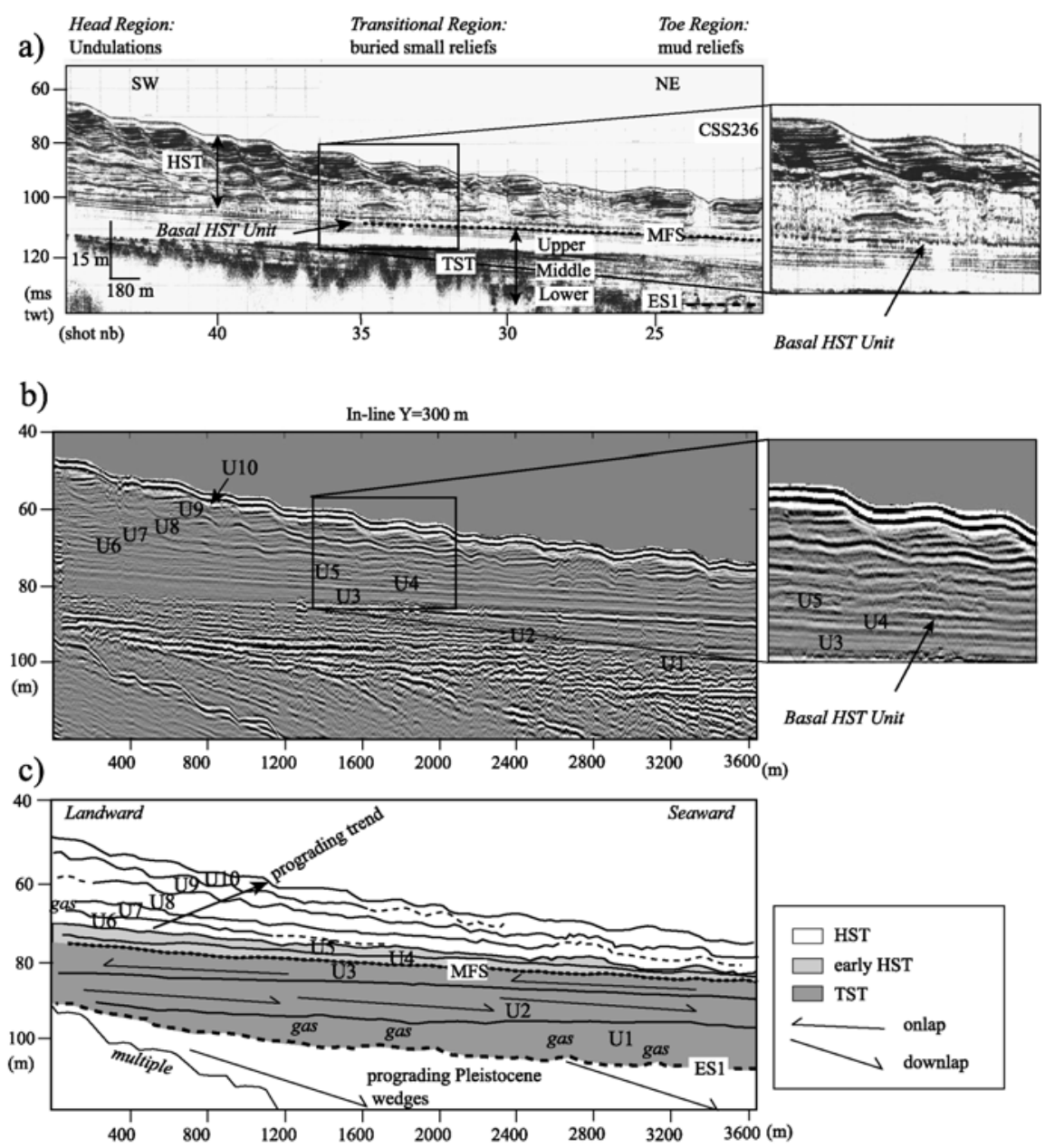

Figure 2. Comparison of in-line profiles acquired using complementary seismic tools at the same location: a) Chirp Profile (labels are from Trincardi and Correggiari, 2000: ES1= erosional surface, MFS= Maximum flooding surface, TST=Transgressive System Tract, HST=High stand System Tract). Note, within the Basal HST, the wipe-outs and locally-enhanced amplitudes of seismic reflectors and the acoustically transparent reliefs (zoom on the right); b) In-line sparker extracted from 3D depth migrated volume showing the seimic units identified in this study. Note the better defined reflectors of the basal HST unit and within the reliefs as compared to the Chirp; c) Interpretative line drawing of the in-line sparker. 
On the central Adriatic shelf offshore Ortona, three shore-parallel regions are distinguished: 1) a head region where the thick HST deposit is affected by undulations. These shore-parallel crests characterised by wavelengths ranging between 50 and $300 \mathrm{~m}$, small vertical amplitudes (1-3 m) and a large lateral continuity (several $\mathrm{km}$ ); 2) a toe region composed of a thinner deposit with elongated mud-relief clusters oriented sub-perpendicular to the shoreline; and 3) an intervening transition zone between the two regions with buried small reliefs and sedimentary features previously interpreted as small-scale extensional faults (Correggiari et al., 2001). Intense shallow seismicity and recurrent tsunami (Tinti et al., 1995) occur in this area located on the foreland basin of the Apennine chain. Modern water currents circulation is characterised by a counter-clockwise gyre with a flow component directed to the SE and parallel to the Italian coast (Poulain, 1999). Regional sedimentological analysis suggests that this circulation pattern has not changed since the onset of the modern sea level highstand (Cattaneo et al., 2003a).

\section{Methods}

In this paper we discuss the interpretation of the VHR 3D seismic volume and compare it to selected sections of conventional sub-bottom profiler (Chirp). The geochronological control on the identified seismic units is assumed from previous work in the area (Asioli, 1999; Calanchi et al., 1998; Cattaneo and Trincardi, 1999; Trincardi and Correggiari, 2000; Oldfield et al., 2003).

The 3D acquisition system developed by IFREMER (Marsset, 2001; Marsset et al., 2002) is capable of being dimensioned in a dynamic way for optimal coverage of geotechnical and geological sites of small extent (2 km by $1 \mathrm{~km}$ ) in water depths up to 200 meters, penetration up to 100 meters and a vertical target resolution of decimetric scale. Detailed methodology and technical aspects of the 3D seismic approach are provided in Marsset (2001), Marsset et al. (2002) and Marsset et al., (2003a). The TRIAD 3D seismic data set was collected in August 2001 using a sparker source (metric resolution) and 4 streamers (6 seismic traces, $2 \mathrm{~m}$ apart) with a $5 \mathrm{~m}$ spacing between streamers (Fig.3). The 3D data acquisition was acquired using a boat speed of 4 nods along a dense grid of profiles with a $10 \mathrm{~m}$ spacing between lines; shoting interval was of $0.5 \mathrm{sec}$ i.e. $1 \mathrm{~m}$. It required 9 days of navigation (daylight only) and 139 seismic profiles, i.e. 350000 shot points or 8.5 million traces or 20 Gbytes of data. The main steps of the processing include: 1) navigation processing : absolute (latitude, longitude) positioning (vessel) and relative (distance) positioning (source and receivers); 2) Quality control (e.g. comparison of seismic bathymetry calculated through simple NMO correction and multibeam bathymetry); and 3) seismic processing (editing, swell filtering and 3D prestack depth migration (Kirchhoff). The processed 3D block consists in a cube of 1827 x 395 elementary ( $2 \mathrm{~m} \times 2 \mathrm{~m}$ ) cells, each cell extending through depth at a $20 \mathrm{~cm}$ sampling interval. Additional information on acquisition and processing can be found in Marsset (2001), Marsset et al. (2002) and Marsset et al., (2003a). In-line and cross-line seismic sections as well as depth slices or cubes have been extracted from the 3D block for interpretation (Fig. 3). Semi-automatic picking of seismic horizons in the 3D block allows to easily elaborate numerical models of the main geological surfaces. 

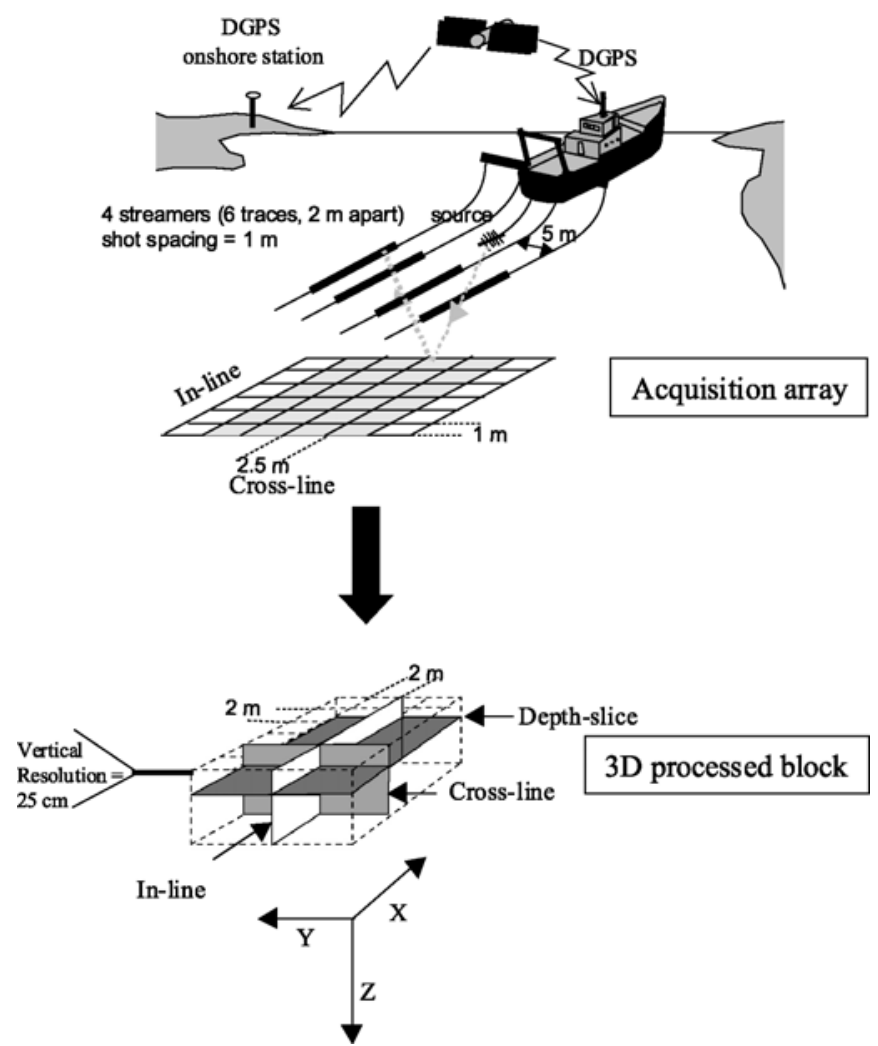

Figure 3. Schematic view of the VHR3D acquisition layout and of the 3D data cube (modified from Marsset et al., 2003a).

\section{Results}

The different seismic units are located on the inner continental shelf above the uppermost regional erosional surface (ES1) capping the Pleistocene prograding wedges (Fig. 2).

\subsection{Description of the seismic units}

Thanks to the 3D data set, 10 units can be distinguished. The seismic units are of various extents (Fig. 2b, Fig. 2c). Units U1 to U5 are laterally extensive, whereas units U6 to U10 are markedly progradational and pinch out more rapidly seaward showing a prograding trend from U6 to U10 (Fig. 2c). All seismic units have a maximal thickness of less than $10 \mathrm{~m}$ and all the surfaces (reflectors) at the top of each seismic unit have an average dip value less than $0.6^{\circ}$ (Table 1). The tops of three units (U2, U4 and U5) display no variation of the average dip along the slope. U1 top marks a clear change where the unit pinches out in the Head region. Units U6 to U10 display a significant average dip change of their top at $\mathrm{X}=1600 \mathrm{~m}$ (Fig. 2c). With regard to their internal structure, seismic units show different characteristics (Fig. 2b). Unit U1 is partially affected by gas, making up difficult to distinguish the internal geometry and the seismic facies. Unit U2 is characterised by internal downlapping reflectors evidencing prograding deposits. Unit U3 is composed of parallel and onlapping reflectors capped by a flat surface that represents the first downlap surface

Unit U4 is very thin and downlaps U3, its thickness decreasing seaward where the unit reduces to only one reflector. Unit U5 is a second thin layer which overlies U4 and shows a 
thickness decreasing seaward together with U4 (Table1). U5 reveals slight undulations in the head region evolving, seawards, to increasingly high reliefs.

\begin{tabular}{|c|c|c|c|c|c|}
\hline Unit & $\begin{array}{l}\text { Max thickness (m) } \\
\text { Head - Toe region }\end{array}$ & $\begin{array}{l}\text { Avera } \\
\text { of uni }\end{array}$ & $\begin{array}{l}\text { ip ( }\left(^{\circ}\right) \text { of top } \\
X=\end{array}$ & $\begin{array}{l}\text { Aver } \\
\text { unit: }\end{array}$ & $\begin{array}{c}\text { ip }\left(^{\circ}\right) \text { of top of } \\
X=\end{array}$ \\
\hline U1 & $2-10$ & 0.35 & $0-800 \mathrm{~m}$ & 0.07 & $800-3200 m$ \\
\hline U2 & $7-9$ & 0.11 & $0-3200 \mathrm{~m}$ & & \\
\hline U3 & $6-5$ & 0.18 & $0-600 m$ & 0.14 & $600-3200 m$ \\
\hline U4 & $3-1$ & 0.14 & $0-3200 \mathrm{~m}$ & & \\
\hline U5 & $3-1$ (3 in reliefs) & 0.11 & $0-3200 \mathrm{~m}$ & & \\
\hline U6 & $6-0$ & 0.21 & $0-1600 \mathrm{~m}$ & 0.11 & $1600-3200 m$ \\
\hline U7 & $5-1$ & 0.35 & $0-1600 \mathrm{~m}$ & 0.14 & $1600-3200 \mathrm{~m}$ \\
\hline U8 & $7-1$ & 0.35 & $0-1600 \mathrm{~m}$ & 0.21 & $1600-3200 \mathrm{~m}$ \\
\hline U9 & $8-2$ & 0.35 & $0-1600 \mathrm{~m}$ & 0.28 & $1600-3200 \mathrm{~m}$ \\
\hline U10 & $5-1$ & 0.50 & $0-1600 \mathrm{~m}$ & 0.28 & $1600-3200 m$ \\
\hline
\end{tabular}

Table 1. Maximum thickness of units and average dip value of the top of units.

Note the major change in dip values at $\mathrm{X}=1600 \mathrm{~m}$ for units U5 to U10 (shaded areas).

Units U6 to U10 show the same seismic facies with seaward prograding clinoform reflectors. Unit U6, with a faint extent seaward compared to underlying units U4 and U5, downlaps the SW part of U5. Its top is slightly undulated. Unit U7 shows the characteristics of U6 with a wider extension, the distal part draping the underlying reliefs of U5. The internal structure of undulations within U7 shows low angle inclined reflectors dipping upstream. Unit U8 emphasises the characteristics of U7. U9 shows the same characteristics as U7 and U8 in the head region where undulations are well developed. In the relief area, the dominant sedimentation style within U9 is filling more than draping. The last unit U10 is unclear at this resolution due to its thin thickness and because of the presence of the very strong sea bottom reflector which masks the superficial sediments. However the detailed examination of the Chirp profiles (Fig. 2a) shows that U10 is made of a very transparent acoustic facies which includes the sea bottom reflector and tends to smooth out the underlying topography.

\subsection{Seafloor and subsurface sedimentary features in the identified seismic units}

The detailed observation of the 3D seismic volume allows to point out two types of sedimentary features: undulations and reliefs (Fig. 4).

Undulations that affect the HST are asymmetric and define a stepwise morphology with broad sub-horizontal flats and narrow seaward-dipping steeper flanks. Internal reflectors are gently landward-dipping when the sediment-wave-like pattern is well developed. Crests of the undulations are translated landward up-section. Seismic reflectors are continuous across the undulations (Fig. 4a, Fig. 5). Undulations locally overlie small isolated clusters and then increasingly high reliefs belonging to unit U5 (Fig. 5). Undulations appear as straight shoreparallel features whereas further seaward they become increasingly sinuous (Fig. 6). This trend is observed at regional scale on bathymetry data offshore Ortona (Fig. 1). Morphobathymetric parameters of these undulations measured at the seafloor are presented by Cattaneo et al. (this volume). 


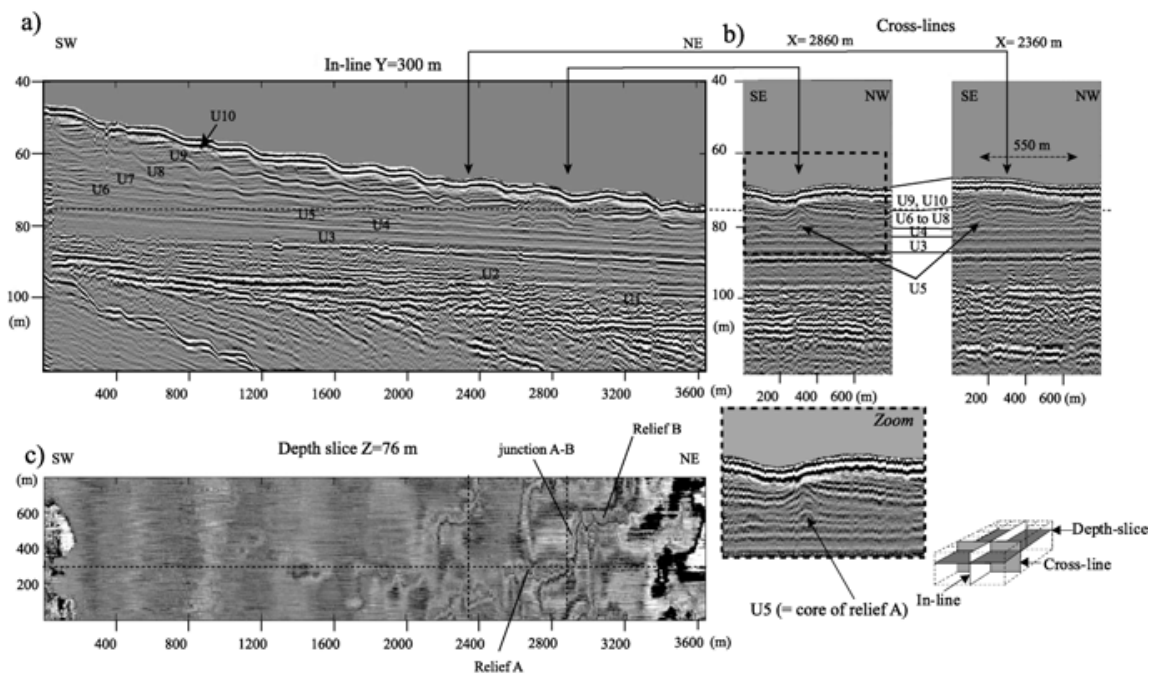

Figure 4. a) Sparker sections extracted from the 3D data set: a) In-line shows the seismic units identified in this study. b) Cross-line illustrates two examples of the regular internal structure of the mud reliefs. Reliefs (units U5 to U8) are symmetric to slightly asymmetric antiforms partially covered by units U9 and U10 that tend to fill the topographic lows between the reliefs. c) Depth slice at $76 \mathrm{~m}$ outlines isolated clusters that form shore-normal alignments and evolve seaward to shore-normal elongated reliefs. Note the shore-parallel junction between the two reliefs $\mathrm{A}$ and $\mathrm{B}$.

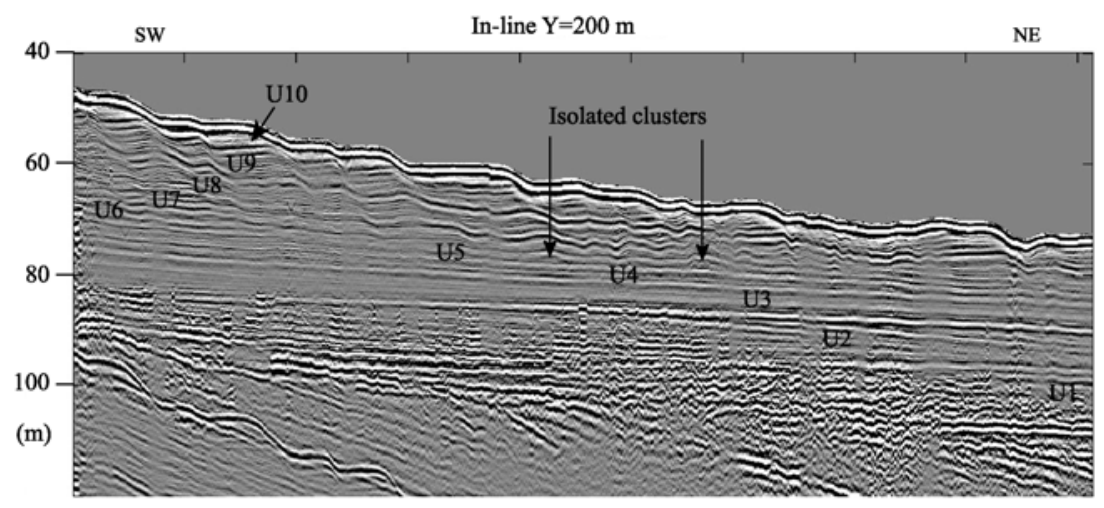

In-line $\mathrm{Y}=450 \mathrm{~m}$

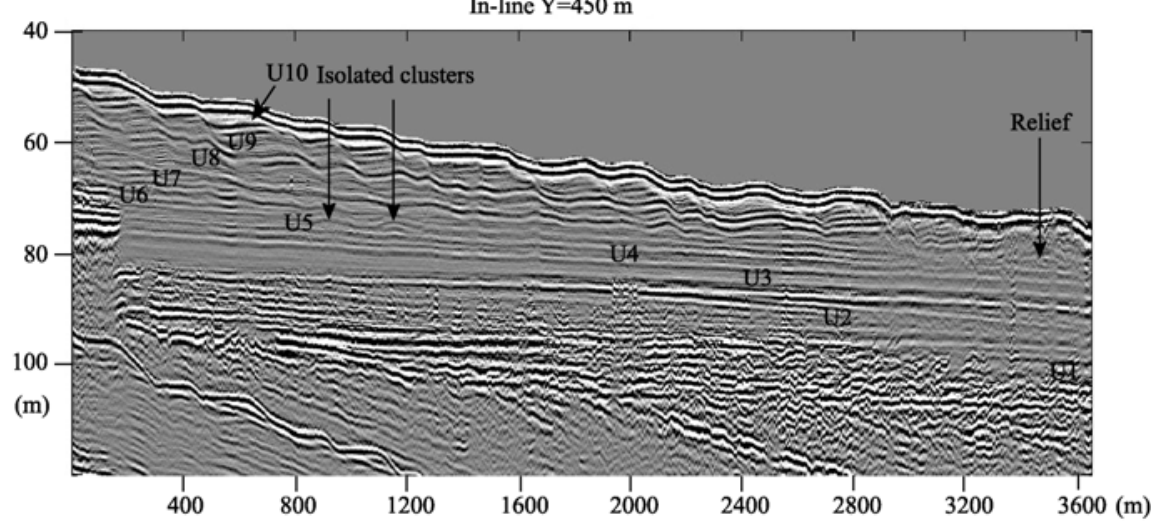

Figure 5. In-lines extracted from the $3 \mathrm{D}$ data cube and illustrating the relation between undulations, that increasingly affect U6 to U10, and the presence of small isolated clusters belonging to U5 (at $\mathrm{X}=1700 \mathrm{~m}$ and $X=2250 \mathrm{~m}$ on Fig. $5 \mathrm{a}$ and at $X=900 \mathrm{~m}$ and $X=1150 \mathrm{~m}$ on Fig. $5 \mathrm{~b}$ ) and that evolve to increasingly high reliefs (at $\mathrm{X}=3450$ on Fig. 5b). Note the continuity of reflectors across undulations. Vertical to horizontal scale exaggeration is approximately $20 \mathrm{x}$ 


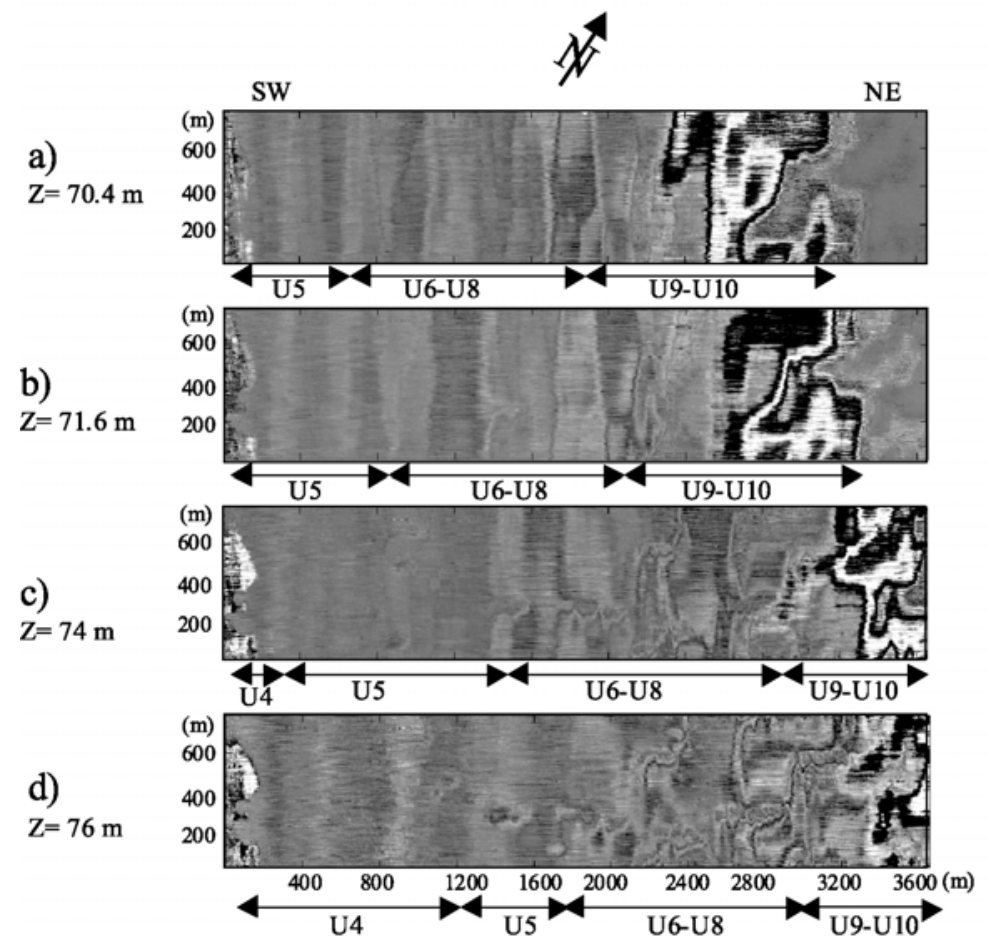

Figure 6. a) to d): Depth slices extracted from the 3D migrated box showing the spatial and stratigraphic evolution of the sedimentary pattern within HST prograding units (U6 to U10). Shore-parallel crests of undulations (U6 to U10) evolve seaward to a complex pattern due to the presence of reliefs belonging to units U5 to U8.

Semi-circular features referred to as "reliefs" by Corregiari et al. (2001) are rooted in small-scale features (few meters high) of unit U5. Up-section, the reliefs appear as antiforms with well defined internal conformable reflectors in units U5 to U8 (Fig. 4a, Fig. 4b), even where they appear transparent on Chirp data (Fig. 2a). The relief axis may be slightly laterally displaced with respect to its base. Spacing between reliefs is about $500 \mathrm{~m}$ (Fig. 4b). In plan view, reliefs appear as alignments of about $400 \mathrm{~m}$ length perpendicular to the regional bathymetric contour (Figure 4c). Reliefs are connected to each other by junctions appearing as shore-parallel elongated features. Junctions mark a differential (asymmetric) filling of morphologic lows between adjacent reliefs with a thick sediment wedge on the NW flanks and a thin sediment fill on the SE flanks (Fig. 4b, Fig. 7: U6 to U8). The 3D view of the relief (U5 to U8) clearly displays an aggradational sedimentary pattern without any significant migration of the internal structure (Fig. 8). On the other hand, units U9 and U10 tend to fill the topographic lows previously defined by the growth of the reliefs thus smoothing the general topography (Fig. 8). Similar to units forming the reliefs (U7 and U8), the thickness of units U9-10 is different on both sides of the reliefs (Figure 4b). The top of the reliefs (U8 top) appears to be erosional with short-distance topographic variations displaying rounded shapes on depth slices (Fig. 8b). The non random spatial distribution of reliefs/junctions point to a general "en echelon" sedimentary pattern that is also observed at the regional scale. In addition, the reliefs that outcrop on the sea-floor, sea-wards from the study area, display the same asymmetric geometry with the gentlest side facing NW (Cattaneo et al., 2003b). These observations are indicative of bottom current activity during and following relief formation. The preferential sediment accumulation occurs on the NW side of the reliefs, i.e. the side facing the dominant along shore current. Moreover, small scale erosion on top of U8 resembles the micro-topography observed on the modern seafloor (Fig. 1) and is consistent with impinging shore-parallel currents. 
Isobath and isopach maps highlight both the short-distance seaward variations and the evolution through time of the sedimentary features (Fig. 9, Fig. 10). Big clusters and well developed reliefs appear where the tops of units U6 to U10 display an average dip change (at $\mathrm{X}=1600 \mathrm{~m}$, Table1).

The detailed observation of the 3D seismic data set also allows to determine the distribution of gas (Fig. 11). With regard to the presence of gas, acoustic masking is widespread in the SW boundary of the 3D study, indicating diffused impregnation of sedimentary units by gas. Acousting masking is concentrated in the landward portion of units $\mathrm{U} 5$ to U10, and in units U1 and U2, indicating impregnation of sedimentary units by gas. No gas is suspected within unit U3 at this resolution.

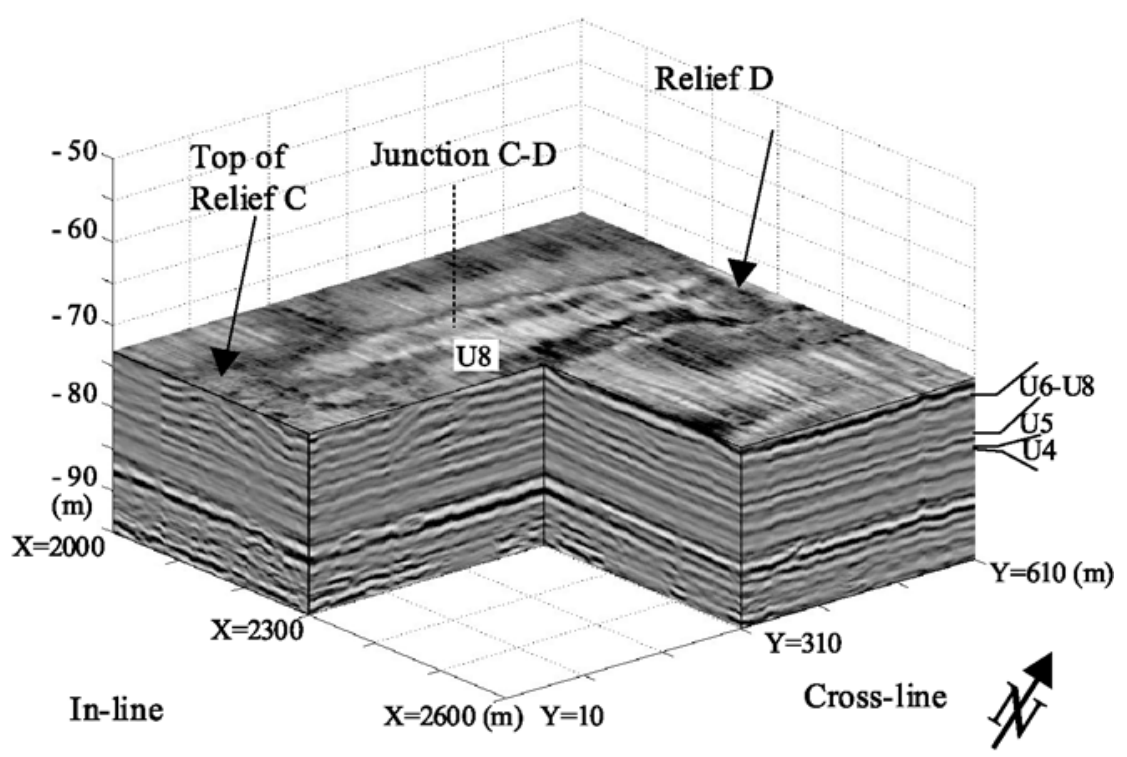

Figure 7. Detailed 3D cube extracted from the total 3D data set (the cube is viewed from SE and coordinates are expressed in $\mathrm{m}$ from their SW corner): the junction between the two reliefs $\mathrm{C}$ and $\mathrm{D}$ corresponds to a preferential deposit on the NW flank of the relief C. 

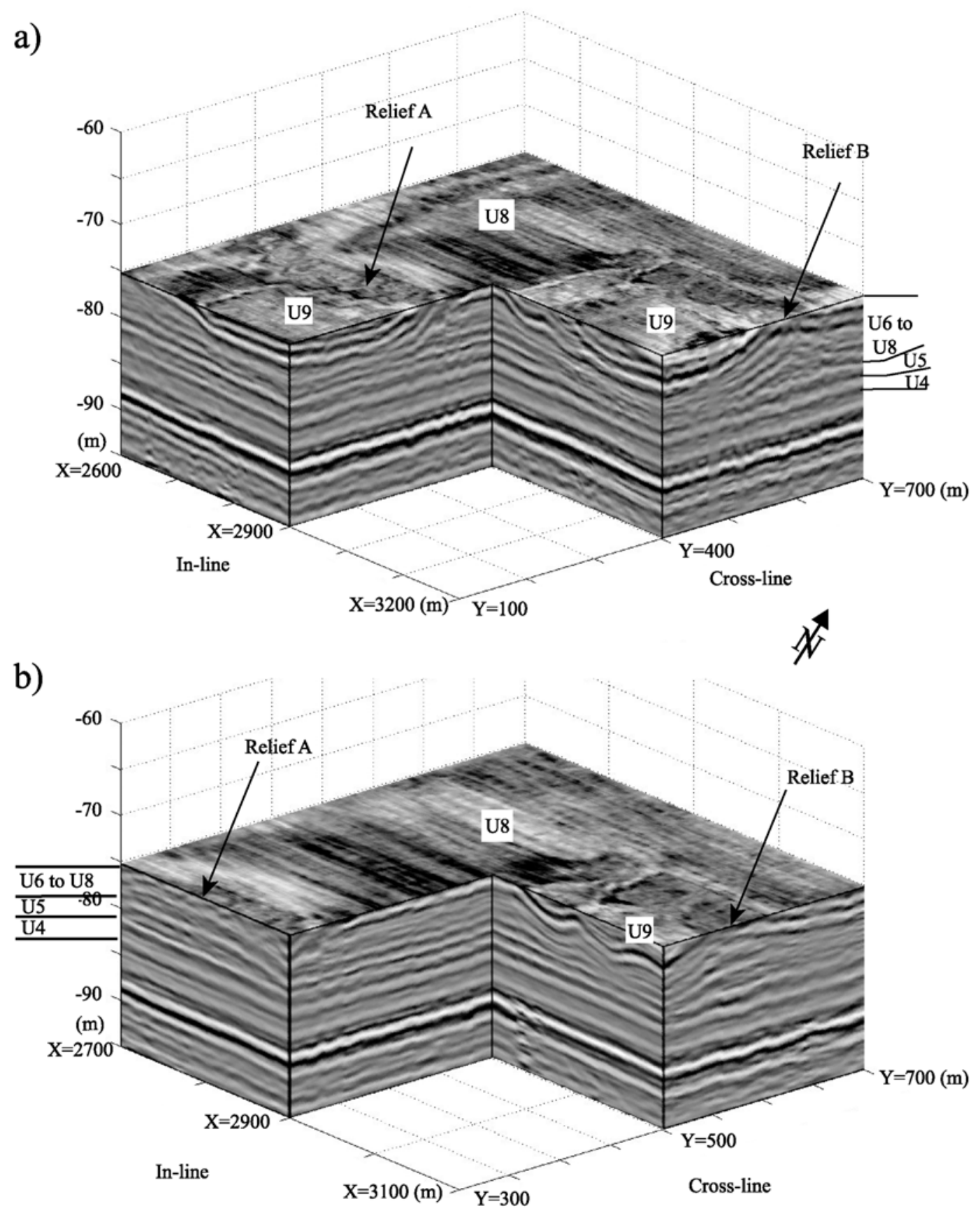

Figure 8. Detailed 3D cubes extracted from the total 3D data set (the cubes are viewed from SE and coordinates are expressed in $\mathrm{m}$ from their SW corner): a) shows the internal structure of the reliefs including: the mounded geometry of unit U5 above the flat unit U4; a stack of units (U6 to U8) that follow the morphology of the underlying mound and create the bulk of the mud relief; the overlying unit U9 filling the topographic lows between adjacent reliefs. Within the relief, reflector geometry is almost symmetrical on cross-line and show subrounded figures at the intersection of the reflectors with the horizontal plane; b) shows the top of relief A characterised by a very undulated surface that seems to be of erosional nature (modified from Marsset et al., 2003b). 


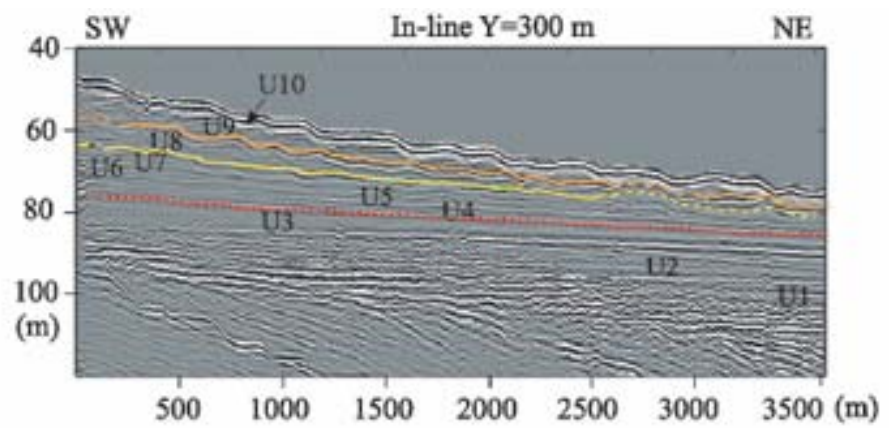

a) Sea-bottom: Isobaths

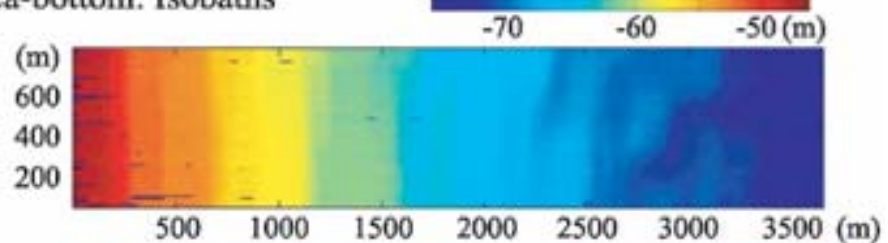

b) U8 Top: Isobaths

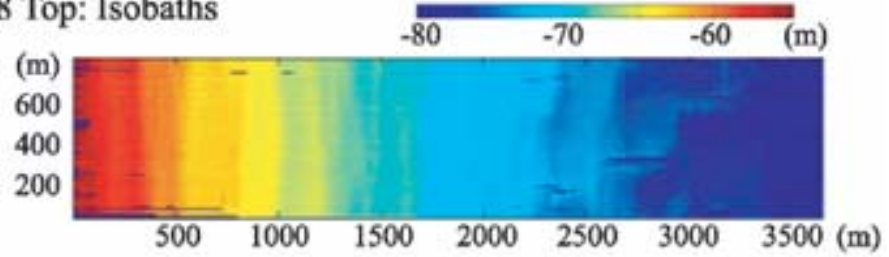

c) U7 Top: Isobaths

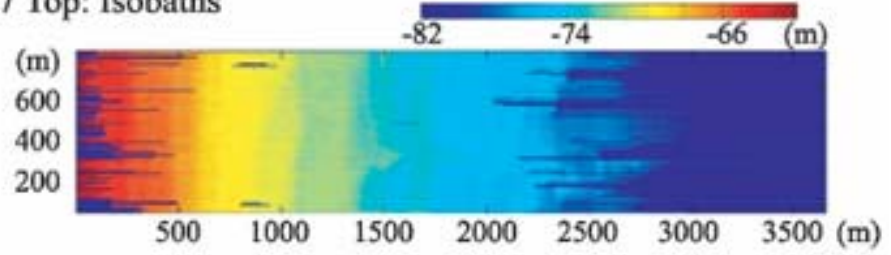

d) MFS: Isobaths

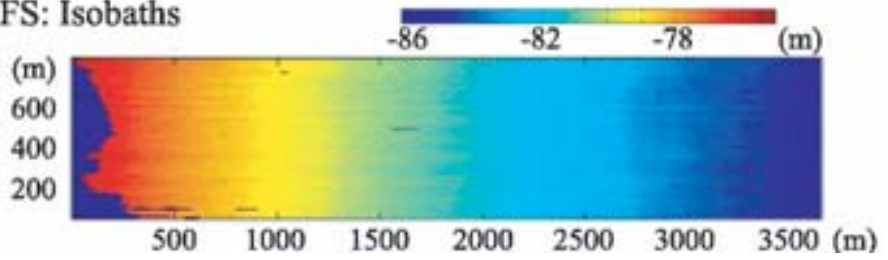

Figure 9. In-line section (at $\mathrm{Y}=300 \mathrm{~m}$ ) with selected horizons (in colour) for which corresponding isobath maps are shown: a) Sea-bottom corresponds to the smoothest topography due to the behaviour of units U9 and U10 that tend to fill the topographic lows; b) The distal part of U8 top displays the "en-echelon" sedimentary pattern; c) U7 top reveals the clusters forming the reliefs in the central part of the area. Note that the distal part of this surface is too thin to allow accurate picking. d) Note the very flat surface of the MFS. 
a) U4 to U10 isopachs

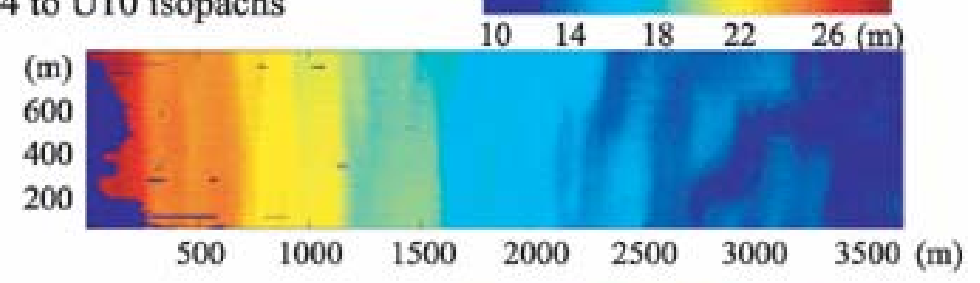

b) U9 \& U10 isopachs

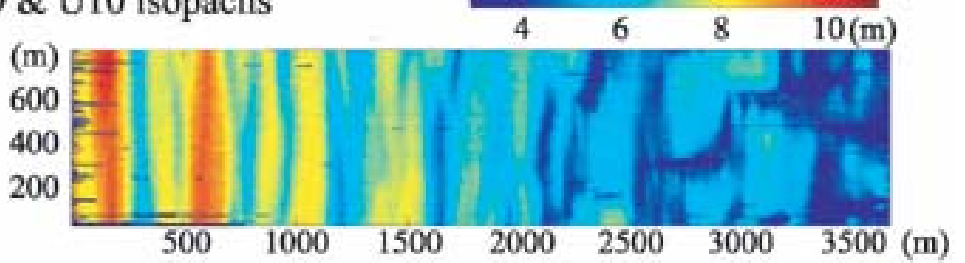

c) U8 isopachs

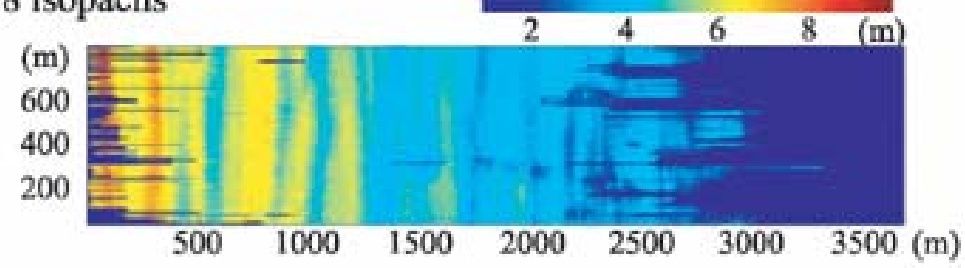

d) U4 to U8 isopachs

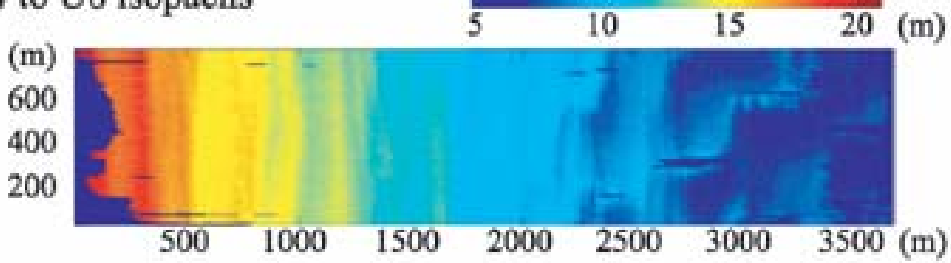

e) $\mathrm{U} 4$ to U7 isopachs

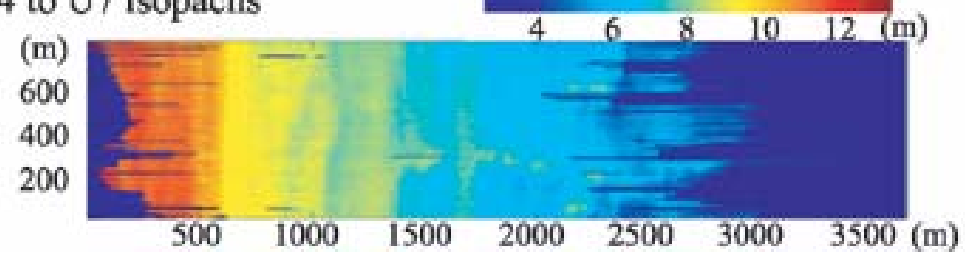

Figure 10. Isopach maps between the various horizons highlighted in the section of fig. $9:$ a) the thickness variation of the whole HST (U4 to U10) displays the seaward transition from linear to complex features in a relatively smoothed pattern; b) the marked crests of U9-U10 clearly display the transition, seaward, from linear to sinuous trend. The distal part of the area illustrates the filling of the topographic lows between the reliefs by these units. c) U8 isopachs show that the distal part of the unit is not reliable due to the difficulties in picking the U8 top. (d) the thickness variation between the relief top and the MFS define the "en echelon" sedimentary pattern made of relief/junction; e) the thickness variation between the U7 top and the MFS clearly evidences that shore-parallel crests are not well developed in these units and that the small-scale reliefs define shorenormal isolated clusters. Note that the distal part is not reliable due to the difficulties in picking the U7 top. 


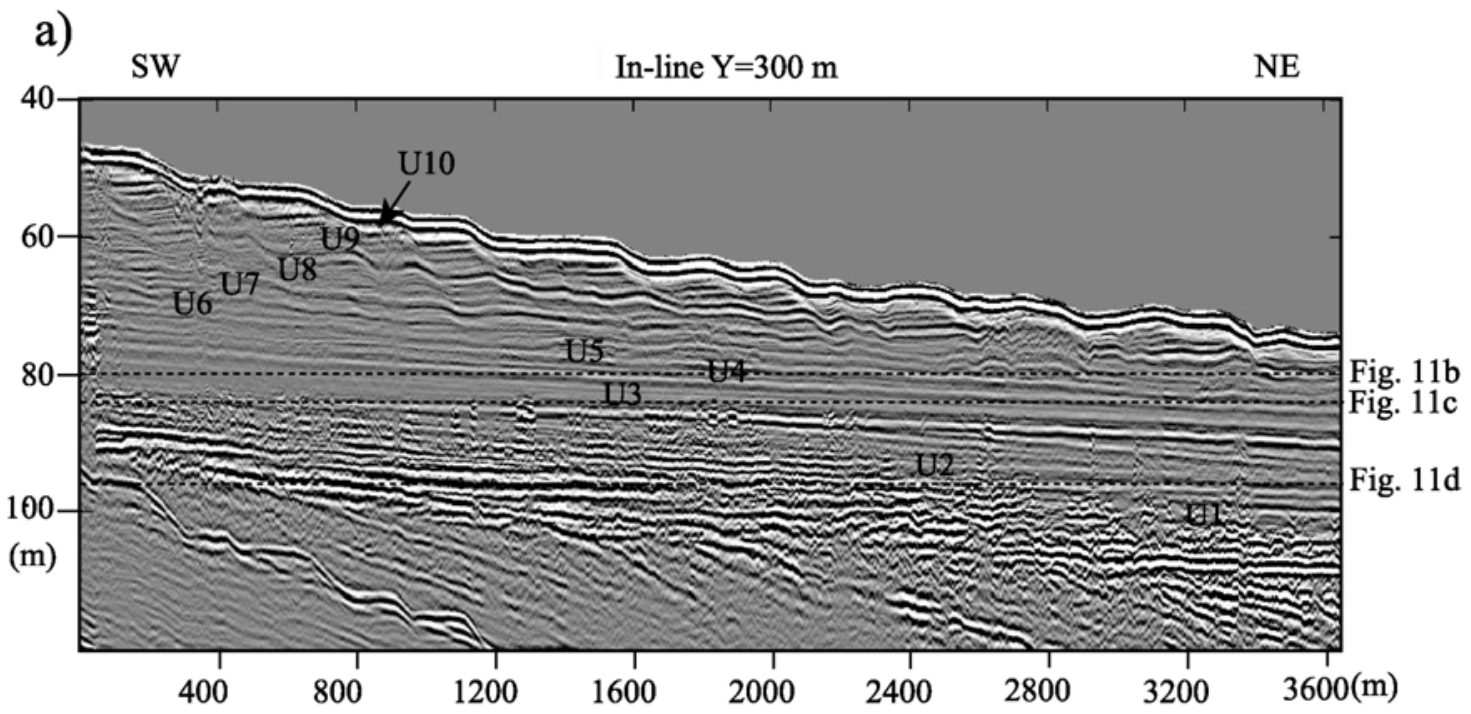

b) Depth slice $Z=81.6 \mathrm{~m}$
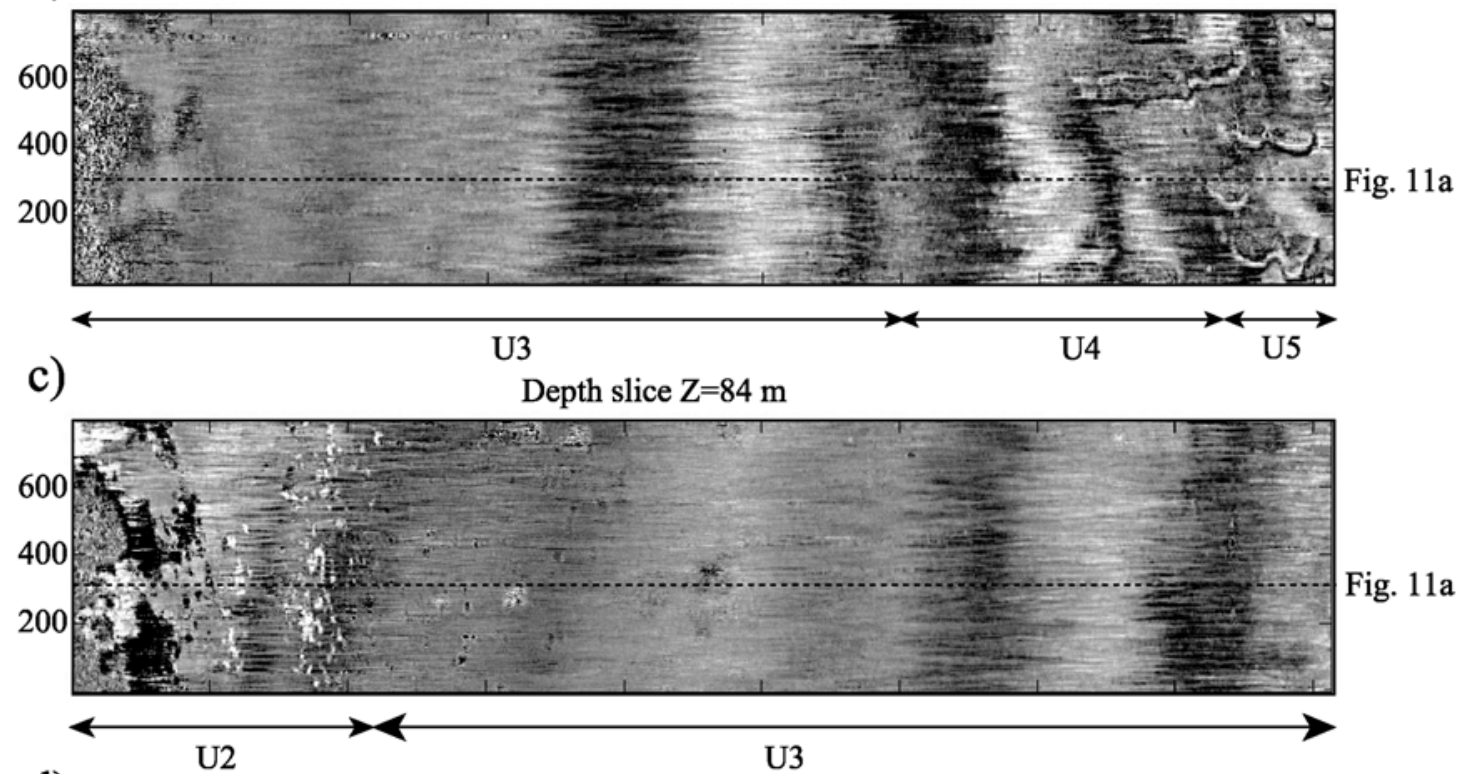

d) Depth slice $\mathrm{Z}=96 \mathrm{~m}$

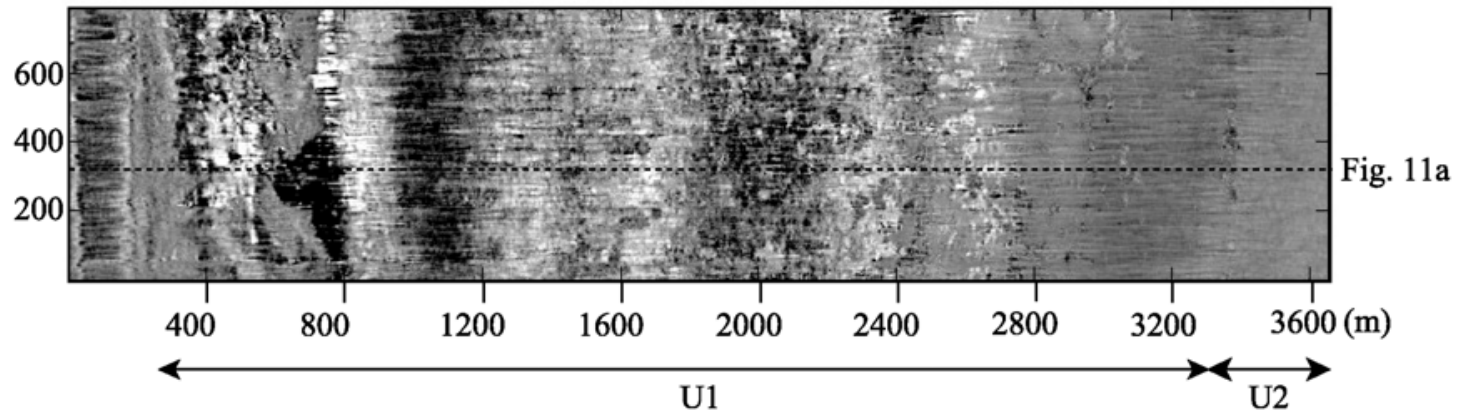

Figure 11. Depth slices extracted from the Triad 3D data cube revealing the non-randomly distribution of gas across seismic units. a) in-line profile; b) slice showing absence of gas within U3, which seems to play the role of a gas-tight layer at this resolution c) slice showing alignments of gas pockets within U2, thus evidencing weak lines along which gas concentrated preferentially; d) slice showing that U1 is partially affected by gas, making it difficult to distinguish the internal geometry and the seismic facies in profiles (modified from Marsset et al., 2003a). 


\subsection{Interpretation and correlation with previous work}

The main seismic units identified by Correggiari et al. (2001) on sub-bottom profiler CHIRP profiles (Fig. 2a) and described above were recognised on the in-line sections of the VHR 3D seismic volume (Fig. 2b, Fig.2c) and compared (Fig. 12), despite their different vertical resolution (ca. $1 \mathrm{~m}$ for the Sparker and $0.2 \mathrm{~m}$ for the Chirp).

Based on the 3D study, three groups of units may be defined as follows (Fig. 12):

- Units U1, U2 and U3 correspond to the three main deposits of the TST formed during the last relative sea-level rise (Cattaneo and Trincardi, 1999). Unit U3, capped by the MFS, represents a possible seal for underlying gas-charged units as confirmed by the Chirp data (Fig. 2a).

- Units U4 and U5 are thin and extensive units that mark the lower HST. Unit U4 includes the basal HST unit that encompasses the condensed section; Unit U5 corresponds to the basal layer of the mud reliefs as defined by Correggiari et al. (2001).

- Units U6 to U10 are wedge-shaped progradational stacked units that become more laterally continuous in a seaward direction and comprise the bulk of the HST mud prism. The geometry and thickness of these units reflect short-term supply fluctuations to the area. Unit U9 can be attributed to deposition during the Little Ice Age (Cattaneo et al., 2003a); Unit U10 is affected by short-distance variations in modern sediment accumulation rates reflecting the interaction between micro-topography and bottom currents (Correggiari et al., 2001).

\subsection{Interest of the 3D approach}

From a methodological point of view, the results of this study confirm the interest of the 3D approach. This approach allows to distinguish between different types of sedimentary features (undulations, reliefs, junctions) within the HST in an unclear transitional area between seafloor undulations and outcropping reliefs (Fig. 13). To understand such a complex geological area requires the resolution achieved in VHR 3D survey (i.e. a spatial resolution with a cross-line adequate with the in-line sampling and with the vertical resolution).

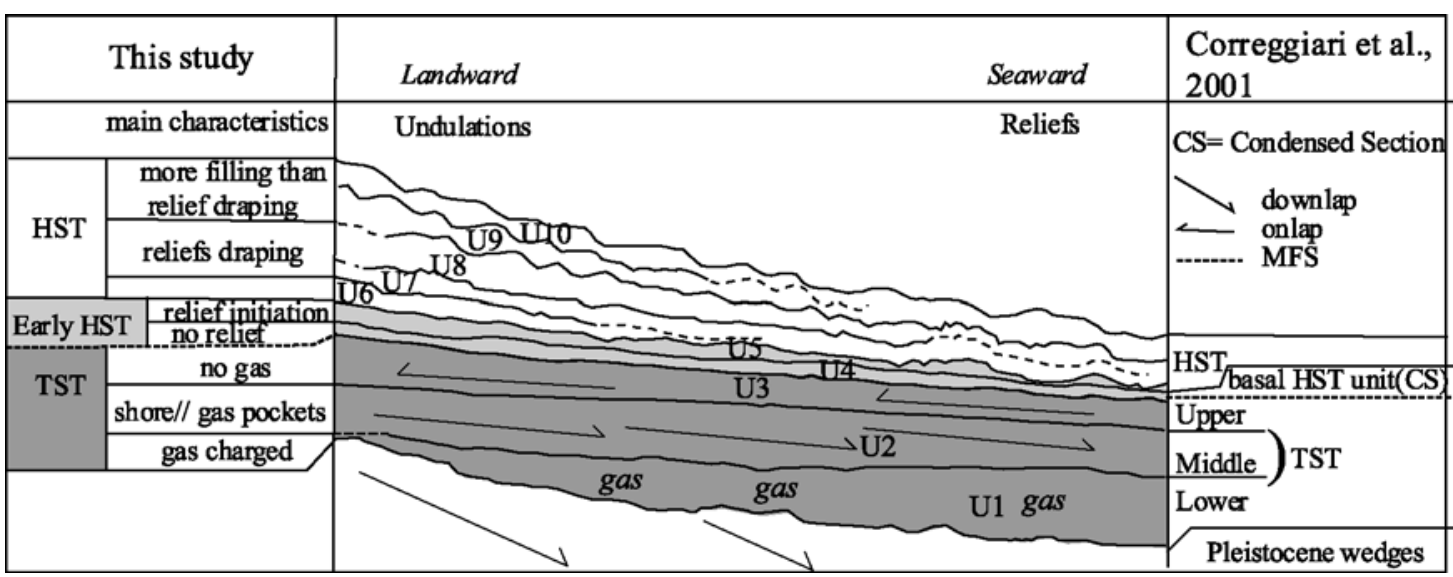

Figure 12. Seismic stratigraphic units defined in the present study and correlation with previous work. Modified from Marsset et al., 2003b 


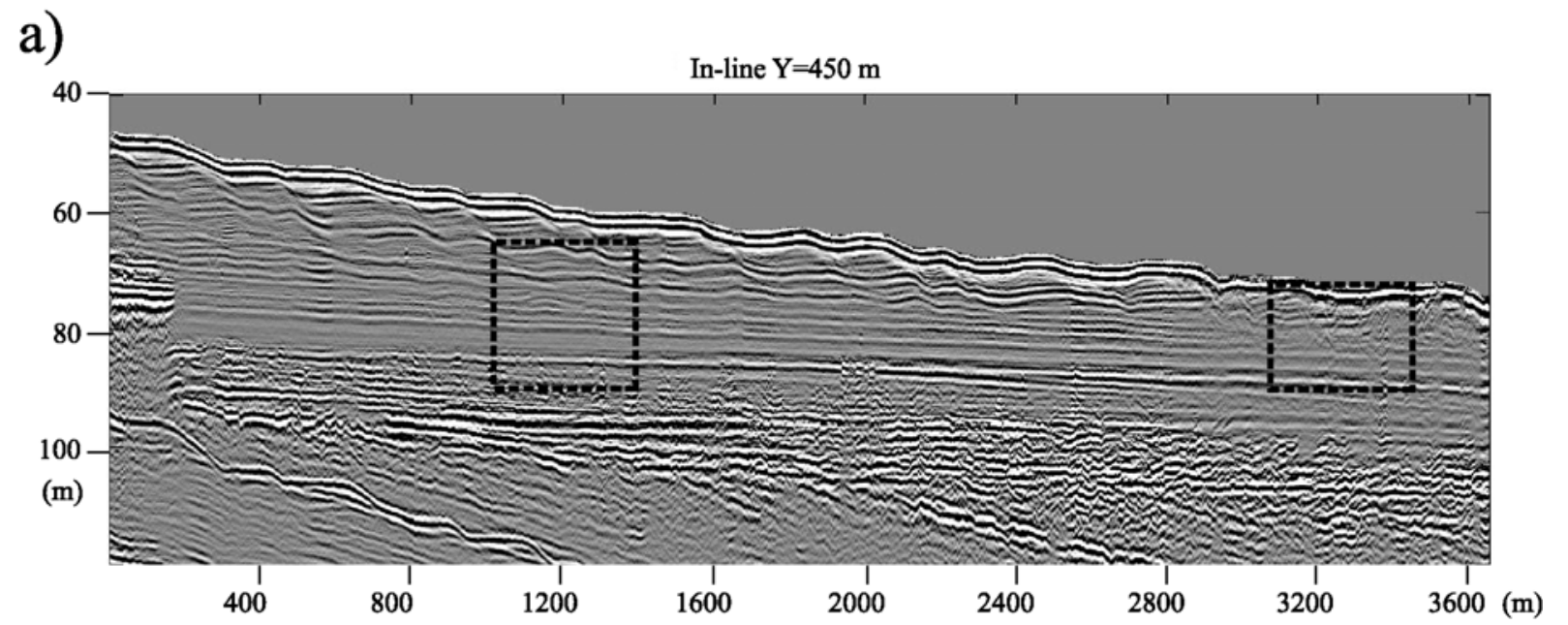

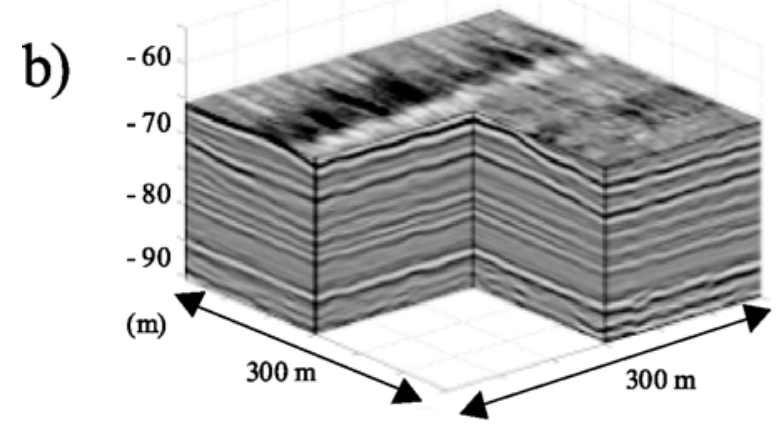

\section{Linear sedimentary feature}

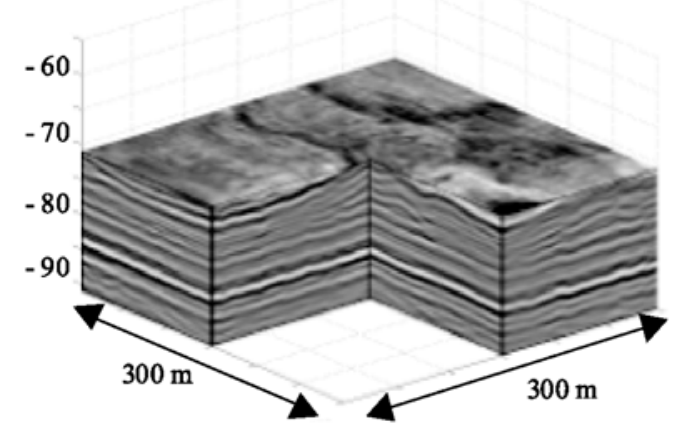

\section{Complex sedimentary} feature

Figure 13. a) In-line section (at $Y=450 \mathrm{~m}$ ); b) 3D cubes underlying the interest of the 3D approach in complex sedimentological environement.

\section{Discussion}

The complex geometries observed within the late-Holocene mud wedge offshore Ortona can be ascribed to two different mechanisms: 1) sediment deformation accompanied by fluidescape (Correggiari et al., 2001); and/or 2) sediment transport and differential deposition by bottom currents.

\subsection{Sediment deformation}

Evidence for sediment deformation comes particularly from the observation of units U4 and U5. On Chirp profiles, high-amplitude reflectors affected by acoustic wipe-out and "pagoda structures" have been previously interpreted as caused by fluid escape from unit U4 (Correggiari et al., 2001). Downslope extension of overlying HST zones in response to fluid expulsion is a plausible deformation mechanism. Cyclic loading engendered by earthquakes or tsunamis is a possible trigger mechanism to create excess pore pressure successively dissipated through deformation and fluid expulsion. In that way, U4 may have acted as a basal weak layer for the HST. Deformation, however, is not associated with any obvious downslope translation of the sedimentary section at the metre-scale resolution of the Triad 3D seismic data. Possible minor offsets are observed on Chirp records at local scale (Correggiari et al., 2001). Unequivocal shear planes are not visible in the 3D data, reducing the possible role 
played by retrogressive failure (Gardner et al., 1999). Nevertheless, we cannot exclude the possibility that some plastic deformation occurred without clear evidence of seismic reflector rupture.

The peculiar spatial distribution of the reliefs along regularly spaced alignments perpendicular to the shoreline is also difficult to explain in term of sedimentary deformation. In addition, the well preserved internal structure of reliefs is difficult to explain by a remolding of the whole sediment deposit forming the relief. A more subtle mechanism (micro-bubbles diffusion) could make deformation easier while limiting sediment mobilisation.

\subsection{Depositional styles and effect of bottom currents}

Transport and deposition by bottom currents may explain at least part of the complex geometries observed within the late-Holocene mud wedge, and more specifically the sedimentary pattern in the undulations after the creation of topographic irregularities in seismic unit U5. It is possible that seafloor undulations formed as sets of sediment waves with shoreline-parallel crests, even if all the cases of sediment waves described in the literature show markedly different characters (Cattaneo et al., this volume). With the resolution of VHR 3D seismics, a landward shift in the crests position is observed, accompanied by occasional presence of gently landward-dipping reflectors. These evidences, however, are not sufficient to conclude that the seafloor undulations migrated upslope as sediment waves, nor allow to reconstruct a clear direction of paleo-flow. The evolution of the sedimentary pattern from U6 to U10 may be interpreted as a change in sediment supply and/or current regime. Moreover, bottom-current activity is indicated by the 3D analysis seaward of the shore-parallel undulations, i.e. in the reliefs area, with a component parallel to the regional bathymetric contour. The depositional processes are mainly recorded by the asymmetric pattern on the flanks of the reliefs in the form of a thicker accumulation on the NW side facing the current and a thinner deposit on the SE side.

The sedimentary units of the HST seem to record an increasing interaction between bottom currents and the topography generated by the growth of the reliefs. The reliefs record predominant aggradation processes and minor migration. Bottom currents, however, are difficult to invoke given the irregular spacing of crests and undulations growth sub-parallel to inferred flow. In addition, the seaward transition from shore-parallel linear crests to sinuous crests, and then to shore-perpendicular elongated reliefs is not easily explained by sediment transport by currents alone. Furthermore, the role of bottom currents has to explain the initiation of the sediment reliefs within unit U5 above a relatively flat surface (top of U4).

\section{Conclusion}

The 3D VHR seismic method used during the TRIAD cruise on the Adriatic shelf allowed to study in detail the sedimentary pattern of a complex area made of two classes of seafloor and subsurface features that are elongated in directions perpendicular to each other. These results confirm that water bottom and its subsurface are by nature 3-dimensional structures and should be treated as such. The use of 2D sections and extrapolation between them may be misleading in some cases. Nevertheless, due to the large amount of data to collect and to process, the 3D method must be restricted to targets of limited extent that have been previously investigated by conventional 2D survey.

The comparison of VHR 3D seismic and CHIRP data proved to be complementary: the two data sets match well and allow the identification and correlation of seismic units visible in both records. Therefore the 3D seismic data cube of limited extent can be correlated to regional seismo-stratigraphic subdivisions. On another hand, features identified in Very High Resolution CHIRP data can be evaluated in 3 dimensions thanks to the information provided 
by the 3D analysis of the sedimentary pattern. It was thus possible to image areas that on CHIRP profiles are seismically blank (the core of mud reliefs), but which show the presence of continuous seismic reflectors in the 3D data set. Also, the results show that a key seismic unit (U5) at the base of the HST may have influenced the geometry of the overlying units.

The origin of the stratigraphic complexity is likely to be related to two mechanisms that are not mutually exclusive: sediment deformation and bottom-current deposition. These two processes may have work together to control distinctive aspects of the observed stratigraphy. Sediment deformation, visible in the particular pattern of unit U5, may result from the presence of shallow fluids and cyclic loading by seismological activity. Depositional processes related to shore-parallel bottom currents seem to have partially controlled the sedimentary pattern especially in the upper part of the sedimentary section; the role of depositional processes seems to have increased through time, as testified by distinctive geometries in some portions of the HST sedimentary section (possible mud waves in the undulation area, differential deposition around the mud reliefs and filling geometries in the upper part of some reliefs). Contrasting geometric patterns (undulation features, alignments of reliefs) possibly result from the interaction of different forcing whose relative importance may have varied through time.

\section{Acknowledgements}

Our results were obtained as part of the Continental Slope Stability project (COSTA) funded by the European Commission under contract EVK3-CT-1999-00006 within the 5th framework programme. This work is part of IFREMER and ISMAR CNR-Bologna (n. 1403) contributions to the EU project COSTA. Data for this paper were collected during the TRIAD cruise onboard the R/V L'Europe. The authors wish to thank F. Marillier, N. Wardell and xxxx for their review and comments, which greatly improved the manuscript. 


\section{References}

Asioli, A., Trincardi, F., Lowe, J.J., Ariztegui, D., Langone, L., Oldfield, F., 1999. Submillennial scale climatic oscillations in the central Adriatic during the Lateglacial: palaeoceanographic implications. Quaternary Science Reviews 20, 1201-1221.

Calanchi, N., Cattaneo, A., Dinelli, E., Gasparotto, G., Lucchini, F., 1998. Tephra layers in Late Quaternary sediments of the central Adriatic Sea. Marine Geology 149, 191-209.

Cattaneo, A., Trincardi, F., 1999. The late-Quaternary transgressive record in the Adriatic epicontinental sea: basin widening and facies partitioning. In: Bergman, K.M., Snedden, J.W. (Eds.). Isolated Shallow Marine Sand Bodies: Sequence Stratigraphic Analysis and Sedimentological Interpretation. SEPM Special Publication 64, 127-146.

Cattaneo, A., Correggiari, A., Langone, L., Trincardi, F., 2003a. The late Holocene Gargano subaqueous delta, Adriatic shelf: Sediment pathways and supply fluctuations. Marine Geology 193, 61-91.

Cattaneo, A., Correggiari, A., Penitenti, D., Trincardi, F., Marsset, T., 2003b. Morphobathymetry of small-scale mud reliefs on the Adriatic shelf. In: Locat, J., Mienert, J., (Eds), Submarine Mass Movements and Their Consequences, $1^{\text {st }}$ International Symposium. Kluwer Ac. Pub. 19, 401-408.

Cattaneo, A., Correggiari, A., Marsset, T., Thomas, Y., Marsset, B., Trincardi, F. Seafloor undulation patterns on the Adriatic shelf and comparison to deep-water sediment waves. Marine Geology, this volume.

Conti, A., Stefanon, A., Zuppi, G.M., 2002. Gas seeps and rock formation in the northern Adriatic Sea. Continental Shelf Research, 22: 2333-2344.

Correggiari, A., Trincardi, F., Langone, L., Roveri, M., 2001. Styles of failure in heavilysedimented highstand prodelta wedges on the Adriatic shelf. Journal of Sedimentary Research 71, 218-236.

Faugères, J.-C., Gonthier, E., Mulder, T., Kenyon, N., Cirac, P., Griboulard, R., Berné, S., Lesuavé, R., 2002. Multi-process generated sediment waves on the Landes Plateau (Bay of Biscay, North Atlantic). Marine Geology 182, 279-302.

Gardner, J.V., Prior D.B., Field, M.E., 1999. Humboldt slide - a large shear-dominated retrogressive slope failure. Marine Geology 154, 323-338.

Hovland, M., Curzi, P.V., 1989. Gas seepage and assumed mud diapirism in the Italian central Adriatic Sea. Marine and Petroleum Geology 6, 161-169.

Lee, H.J., Syvitski, J.P.M., Parker, G., Orange, D., Locat, J., Hutton W.H., Imran, J., 2002 Turbidity-current generated sediment waves: modeling and field examples. Marine Geology.

Marsset, B., 2001. Very High Resolution marine 3D seismic method for detailed site investigation. Final report, Contract MAST3 MAS3-CT97-0121.

Marsset, B., Thomas, Y., Thereau, E., Didailler, S., Marsset, T., Cochonat, P., Cattaneo, A. . 2003a. Very high resolution 3d seismic imaging of a complex shelf structure in the adriatic sea. . In: Locat, J., Mienert, J., (Eds), Submarine Mass Movements and Their Consequences, $1^{\text {st }}$ International Symposium. Kluwer Ac. Pub. 19, 441-448.

Marsset, T., Marsset, B., Thomas Y., Didailler, S., 2002. Very High Resolution 3D seismic: a new imaging tool for sub-bottom profiling. C.R. Geoscience 334, 403-408.

Marsset, T., Cattaneo, A., Marsset, B., Thomas, Y., Cochonat, P., Trincardi, F. 2003-b. Detailed anatomy of Late-Holocene deposits on the Adriatic shelf from 3D Very High Resolution seismic data (Triad survey). . In: Locat, J., Mienert, J., (Eds), Submarine Mass Movements and Their Consequences, $1^{\text {st }}$ International Symposium. Kluwer Ac. Pub. 19, 449-458.

Oldfield, F., Asioli, A., Accorsi, C.A., Mercuri, A.M., Juggins, S., Langone, L., Rolph, T., Trincardi, F., Wolff, G., Gibbs, Z., Vigliotti, L., Frignani M., Van der post, K., Branch, N., 
2003. A high resolution late Holocene palaeo environmental record from the central Adriatic Sea. Quaternary Science Reviews 22, 319-342.

Poulain, P.-M., 1999. Adriatic Sea surface circulation as derived from drifter data between 1990 and 1999. Journal of Marine Systems 29, 3-32.

Ridente, D., Trincardi, F., 2002. Eustatic and tectonic control on deposition and lateral variability of Quaternary regressive sequences in the Adriatic basin (Italy). Marine Geology 184, 273-293.

Tinti, S., Maramai, A., Favali, P., 1995. The Gargano Promontory: an important Italian seismogenetic-tsunamigenetic area. Marine Geology 122, 227-241.

Trincardi, F., Correggiari, A., 2000. Quaternary forced regression deposits in the Adriatic basin and the record of composite sea-level cycles. In: Hunt, D., Gawthorpe, R.L. (Eds). Sediment Responses to Forced Regressions. Geological Society Special Publication 172, 245-269.

Trincardi, F., Cattaneo, A., Correggiari, A., Masson, D.G., Hünherbach, V., Jacobs, C., Carrà, D., Magagnoli, A., Penitenti, D., Ridente, D., Roveri, M, 2000. Evidence of giant fluidescape features in late-Holocene deposits on the Adriatic shelf. Giornale di Geologia 62, 528. 